University of Nebraska - Lincoln

DigitalCommons@University of Nebraska - Lincoln

Papers in the Earth and Atmospheric Sciences

Earth and Atmospheric Sciences, Department

2009

\title{
The Nature and Origin of Decadal to Millennial Scale Climate Variability in the Southern Tropics of South America: The Holocene Record of Lago Umayo, Peru
}

\author{
Paul A. Baker \\ Duke University, pbaker@duke.edu \\ Sherilyn C. Fritz \\ University of Nebraska-Lincoln, sfritz2@unl.edu \\ Stephen J. Burns \\ University of Massachusetts, Amherst \\ Erik Ekdahl \\ University of Nebraska-Lincoln \\ CAtherine A. Rigsby \\ East Carolina University
}

Follow this and additional works at: https://digitalcommons.unl.edu/geosciencefacpub

Part of the Earth Sciences Commons

Baker, Paul A.; Fritz, Sherilyn C.; Burns, Stephen J.; Ekdahl, Erik; and Rigsby, CAtherine A., "The Nature and Origin of Decadal to Millennial Scale Climate Variability in the Southern Tropics of South America: The Holocene Record of Lago Umayo, Peru" (2009). Papers in the Earth and Atmospheric Sciences. 243. https://digitalcommons.unl.edu/geosciencefacpub/243

This Article is brought to you for free and open access by the Earth and Atmospheric Sciences, Department of at DigitalCommons@University of Nebraska - Lincoln. It has been accepted for inclusion in Papers in the Earth and Atmospheric Sciences by an authorized administrator of DigitalCommons@University of Nebraska - Lincoln. 
Published (as Chapter 13) in Françoise Vimeux, Florence Sylvestre, \& Myriam Khodri (eds.). Past Climate Variability in South America and Surrounding Regions: From the Last

Glacial Maximum to the Holocene, Developments in Paleoenvironmental Research 14

(Springer, 2009), pp. 301-322; doi: 10.1007/978-90-481-2672-9_13

Copyright (C) 2009 Springer Science+Business Media B.V. Used by permission.

\title{
The Nature and Origin of Decadal to Millennial Scale Climate Variability in the Southern Tropics of South America: The Holocene Record of Lago Umayo, Peru
}

\author{
Paul A. Baker, ${ }^{1}$ Sherilyn C. Fritz, ${ }^{2}$ Stephen J. Burns, ${ }^{3}$ \\ Erik Ekdahl, ${ }^{2}$ and Catherine A. Rigsby ${ }^{4}$ \\ 1. Duke University \\ 2. University of Nebraska-Lincoln \\ 3. University of Massachusetts, Amherst \\ 4. East Carolina University \\ Corresponding author - P. A. Baker, Division of Earth and Ocean Sciences, \\ Duke University, Durham, NC 27708, USA; e-mail pbaker@duke.edu
}

\begin{abstract}
This paper serves two purposes: to review current ideas about the nature and forcing of decadal to millennial scale precipitation variation in the southern tropics of South America during the late Quaternary and to present a new methodology for the reconstruction of precipitation as applied to a Holocene stable isotopic record of carbonate sediments in a tropical Andean lake, Lago Umayo, Peru. The basic thesis of the first part of the paper is that, although modern instrumental records suffice for deducing climate variability at decadal and shorter time scales, these records cannot adequately characterize the nature and forcing of lower-frequency climate variation. Understanding the nature of multi-decadal to millennial-scale climate variation and the mechanisms of large abrupt climate change is best derived from paleoclimatic time series. Tropical Atlantic sea-surface temperature variation is a significant control on tropical South American paleoclimate at these longer time scales. In the second part of the paper, an original method is presented for quantitatively reconstructing precipitation. This method utilizes the well-known relationship between the stable isotopic composition of precipitation and the amount of precipitation, a relationship that is highly significant in many tropical locales. Due to many simplifying assumptions, the reconstruction should be considered to be tentative.

A $\sim 12 \%$ increase in precipitation ( $\sim 570$ to $\left.650 \mathrm{~mm} \mathrm{a}^{-1}\right)$ at $4750 \mathrm{cal}$ year BP is consistent with the $6 \%$ increase in summer insolation at this latitude over the same period. However, the increase in precipitation was neither unidirectional nor gradual. Instead, every 240 years on average, precipitation increased or decreased by at least $\sim 8 \%$ for periods lasting on average 100 years. The largest of these events had $\sim 15 \%$ positive or negative departures from the long-term mean precipitation. These southern tropical wet events apparently coincided with periods of low sea-surface temperatures in the high-latitude North Atlantic, supporting a hypothesis of a tropical North Atlantic
\end{abstract}


sea-surface temperature control on tropical South American precipitation at decadal to millennial scales.

Keywords: paleoclimate, precipitation, oxygen isotopes, tropical South America

\section{Introduction}

The modern climate of tropical South America is known only from a short, sparse, and incomplete instrumental record. In fact, there is only one weather station within the entire Amazon basin (Manaus, Brazil) with a century of complete precipitation data. Although the instrumental data that do exist may suffice for deducing modern climate variability at decadal and shorter time scales, they are clearly insufficient for understanding lower-frequency climate variability of the region and for elucidating mechanisms of large, abrupt climate changes that are, until now, only observable in the paleoclimatic record.

Discounting long-term secular trends, the instrumental record of South American climate displays three main continent-wide patterns of variability related to three main modes of climate variability (recently reviewed by Garreaud et al. 2008): (1) El Niño-Southern Oscillation (ENSO), (2) the Pacific Decadal Oscillation (PDO), and (3) the Southern Annular Mode (SAM) or Antarctic Oscillation (AAO). However, there is some evidence suggesting that these patterns of variability are not independent of each other. For example, the first two modes, ENSO and PDO, have similar spatial patterns of forcing and produce very similar spatial patterns of precipitation anomalies (see Figure 10 of Garreaud et al. 2008). Although the forcing footprint of the SAM mode is quite different from that of the other two modes (Figure 6 of Garreaud et al. 2008), the SAM also produces a similar spatial pattern of precipitation response (albeit of reversed sign) when compared with the other two modes.

Furthermore, in most regions of the South American continent these three remote forcings account for only a small part of the total climate variability. For example, for the period 1950-1999, ENSO variability explains a maximum of twothirds of the inter-annual variability of precipitation in some regions of southern tropical South America (Garreaud et al. 2008), yet over most of the continent, south of the equator, precipitation variability is not significantly correlated with ENSO. Furthermore, because ENSO forcing is non-stationary in time and space, the spatio-temporal patterns of its teleconnection are also non-stationary. For example, Torrence and Webster (1999) showed that the periods 1875-1920 and 1960-1990 were periods of relatively high ENSO variability (high variance of the Southern Oscillation (SOI) and Niño-3 indices), whereas 1920-1960 was a period of low ENSO variability and a period of low coherency between ENSO and Indian monsoonal precipitation. In the North Atlantic region, Sutton and Hodson (2003) showed that ENSO had a significant impact on climate variability during some time periods, but during the period 1910-1960, this influence waned. Aceituno and Montecinos (1993) illustrated the non-stationarity of the ENSO teleconnection in South America, with several examples showing the changing correlation between SOI and annual precipitation. As in the Asian monsoonal and 
North Atlantic regions, Aceituno and Montecinos (1993) found that 1920-1960 was a period of insignificant correlation between SOI and regional precipitation at sites scattered throughout southern tropical South America. Hastenrath and co-workers (2004) also found that the correlation between SOI and wet-season precipitation on the South American Altiplano changed from insignificant during the period 1915-1957 to significant (at the 95\% level) during the period 19581984. These studies all illustrate the perils of too narrowly interpreting past climate variability based solely upon lessons drawn from the short and imperfect instrumental record (what Seager and Battisti (2007) refer to as "limitations of the ENSO blueprint").

The spatio-temporal patterns of variability derived from statistical analyses of climate depend on the particular climate variable being analyzed, the period of the record being considered, and the boundaries of the domain under consideration. For example, a significant pattern of climate variability, not found in continent-wide analyses, emerges when analysis of precipitation variability is limited to the tropical sector of South America (e.g. EOF-3 of Liu 2008). On roughly decadal timescales, small, but persistent, sea-surface temperature (SST) anomalies (superimposed upon much larger intra-annual variability) develop in the northern and southern tropical Atlantic. These SST anomalies (not completely independent of ENSO forcing) are, in part, maintained by regional wind-evaporation-SST feedback (Chang et al. 1997). The SST anomalies produce anomalous north-south shifts of the ITCZ and its embedded atmospheric circulations toward the warmer hemisphere (e.g. Chiang and Koutavas 2004). The SST and circulation anomalies are associated with significant perturbations of precipitation along the northeastern coastal region of South America (e.g. Hastenrath and Greischar 1993, Nobre and Shukia 1996) and throughout the entire Amazon basin south of the equator (Zeng et al. 2008). In boreal winter, tropical Atlantic SST anomalies may be organized into an alternating zonal SST anomaly pattern that extends into higher northern and southern latitudes of the Atlantic and that varies on decadal timescales (Xie and Tanimoto 1998, Xie and Carton 2004).

Atlantic variability, although significant, is not a dominant factor in forcing tropical South American climate variability during the instrumental period. However, there is a great deal of evidence pointing towards a much more important role for the Atlantic in forcing large, persistent, and sometimes abrupt, climate changes in tropical South America in the past, perhaps in synchrony with yet larger-scale ocean-atmosphere regime shifts. In the instrumental period, annual SST anomalies in the northern tropical Atlantic are rarely greater than $1 \mathrm{~K}$ (and their correlations with higher-latitude North Atlantic SSTs are only marginally significant), thus we might expect relatively weak forcing of terrestrial climate variability. However, paleoceanographic studies reveal past periods of much larger decreases (relative to today) of northern tropical Atlantic SST. For example, during the Last Glacial Maximum, SSTs in the northern tropical Atlantic were on average about $3 \mathrm{~K}$ lower than modern, while SSTs in the southern tropical Atlantic and the northern subtropical gyre were similar to modern (Mix et al. 1999). Northern tropical Atlantic SST apparently cooled in concert with high latitude 
North Atlantic SST, while SST in the sub-tropical gyre did not change, in effect causing a persistent and greatly amplified North Atlantic SST tripole. Paleoceanographic evidence is consistent with a similar SST pattern in the North Atlantic during all of the Pleistocene (glacial stages, stadials, and Heinrich events) and Holocene (Bond events) cold events. Irrespective of other forcings (global temperature, insolation, land-surface changes, etc.), the great difference between these past Atlantic SSTs and modern Atlantic SSTs must have forced a very large increase (decrease) in southern (northern) tropical South American precipitation, relative to modern, during the North Atlantic cold events. Large precipitation increases in the southern tropics of South America synchronous with cold events in high northern latitudes have been observed at multi-decadal to millennial time scales in lake and ice-core paleoclimate records from the Altiplano of Peru and Bolivia (Baker et al. 2001a,b, 2005, Hoffmann et al. 2003, Ramirez et al. 2003), speleothem records from the exit region of the South American summer monsoon (Cruz et al. 2005, 2006, Wang et al. 2006, 2007) and from the Nordeste (Wang et al. 2004), and paleoceanographic records of discharge offshore of the Nordeste (Arz et al. 1998, Jennerjahn et al. 2002). Precipitation decreases during North Atlantic cold events have been observed in northern tropical South America in the records from the Cariaco Basin (Black et al. 1999, 2004, Haug et al. 2001, 2003, Peterson et al. 2000, Peterson and Haug 2006).

Climate model simulations provide strong support for both the sensitivity of tropical South American precipitation to North Atlantic SST (e.g. Harris et al. 2008, Zeng et al. 2008) and the postulated linkage between North Atlantic cold events, north tropical Atlantic cold SSTs, and tropical South American precipitation. Broccoli and co-workers (2006) pointed out that many different climate simulations by different groups (e.g. Vellinga and Wood 2002,; Chiang and Bitz 2005, Zhang and Delworth 2005) using models of different complexities and a variety of forcing and boundary conditions, all produce increased (decreased) precipitation south (north) of the equator in tropical South America during North Atlantic cold events. These simulations, no matter what the original intent of the modelers (for example Vellinga and Wood 2002, were addressing future climate change scenarios), are relevant to all of the Quaternary-age North Atlantic cold periods that we previously listed. The relationship between tropical South American precipitation and tropical Atlantic SST is the most robust result of all of these simulations and is completely consistent with paleoclimate results from the region. Furthermore, the near global-scale, the amplitude, and the abruptness of both simulated and observed past climate changes seem to require a major atmospheric reorganization perhaps into an alternate state as envisioned by Seager and Battisti (2007).

In this paper, our purposes are two-fold. First, we briefly review the studies most relevant to the proposition of tropical Atlantic control on tropical South American paleoclimate through the late Pleistocene and Holocene (with emphasis on the latter). Then we present new results from a study of stable oxygen isotopic ratios of carbonate sediments in Lago Umayo (Peru), that aims to quantify past changes in precipitation amount in order to clarify the amplitude and duration of Holocene climate variation in the southern tropical Andes. The novel as- 
pect of this reconstruction is the methodology for quantitatively reconstructing precipitation. Specifically, we introduce an equation that relates the stable isotopic composition of precipitation and the amount of precipitation, a relationship that is highly significant in many tropical locales, into the standard equation for determining the isotopic balance of a lake. Our original approach allows the direct calculation of precipitation amount. However, because we do not have sufficient knowledge of the climate and hydrology of the modern Lago Umayo watershed, we have chosen to make several simplifying assumptions for our calculations. Thus, our approach is meant to be demonstrative more than definitive and the results of our reconstruction should be considered to be tentative.

\section{Precipitation in Tropical South America During the Late Quaternary and its Relationship to Tropical Atlantic Variability}

In this section, we discuss a selection of paleoclimatic records that we believe most accurately reflect the large-scale patterns of precipitation change in tropical South America through the late Quaternary. These reconstructions share the characteristics of accurate dating and high fidelity recording of precipitation.

Long paleoclimatic records demonstrate that orbital control of insolation has played a major role in forcing precipitation in both northern and southern tropical South America. In southern tropical South America, the water level of Lake Titicaca, reconstructed from chemical, isotopic, and paleoecological measurements of deep drill cores (Fritz et al. 2007), rose during global glacial stages and fell dramatically during interglacial stages, although, the extent to which this water balance reflects global temperature change or regional precipitation change is still an open question. Nevertheless, the Lake Titicaca drill core record is the first southern tropical record in South America to clearly indicate that the largest amplitude changes in water balance during the late Quaternary occur on 100,000 year time scales. This finding has implications for the ongoing debate about climate variability and the origin of species in the neotropics.

On precessional timescales (order $10^{4}$ years), the regional-scale patterns of precipitation are more clear-cut. Precipitation changes in the northern and southern tropics of South America are generally in phase with summer insolation maxima (in the respective hemispheres), thus anti-phased with each other. In the southern tropics, several records clearly demonstrate the coherence between summer insolation and the abundance of summer monsoonal precipitation. For example, widespread drying across the southern tropics during the early and middle Holocene (e.g. Cross et al. 2000, Seltzer et al. 2000, Mayle and Power 2008) (Figure 1) broadly coincided with the summer insolation minimum centered at 10,000 years BP when top-of-the-atmosphere insolation was $7 \%$ lower at $20^{\circ} \mathrm{S}$ than its maximum during the Last Glacial Maximum at 20,000 years BP (data from Berger and Loutre 1991). For reference, this change in summer insolation of $34 \mathrm{~W} \mathrm{~m}^{-2}$ is about $20 \%$ of the total intra-annual range of in- 


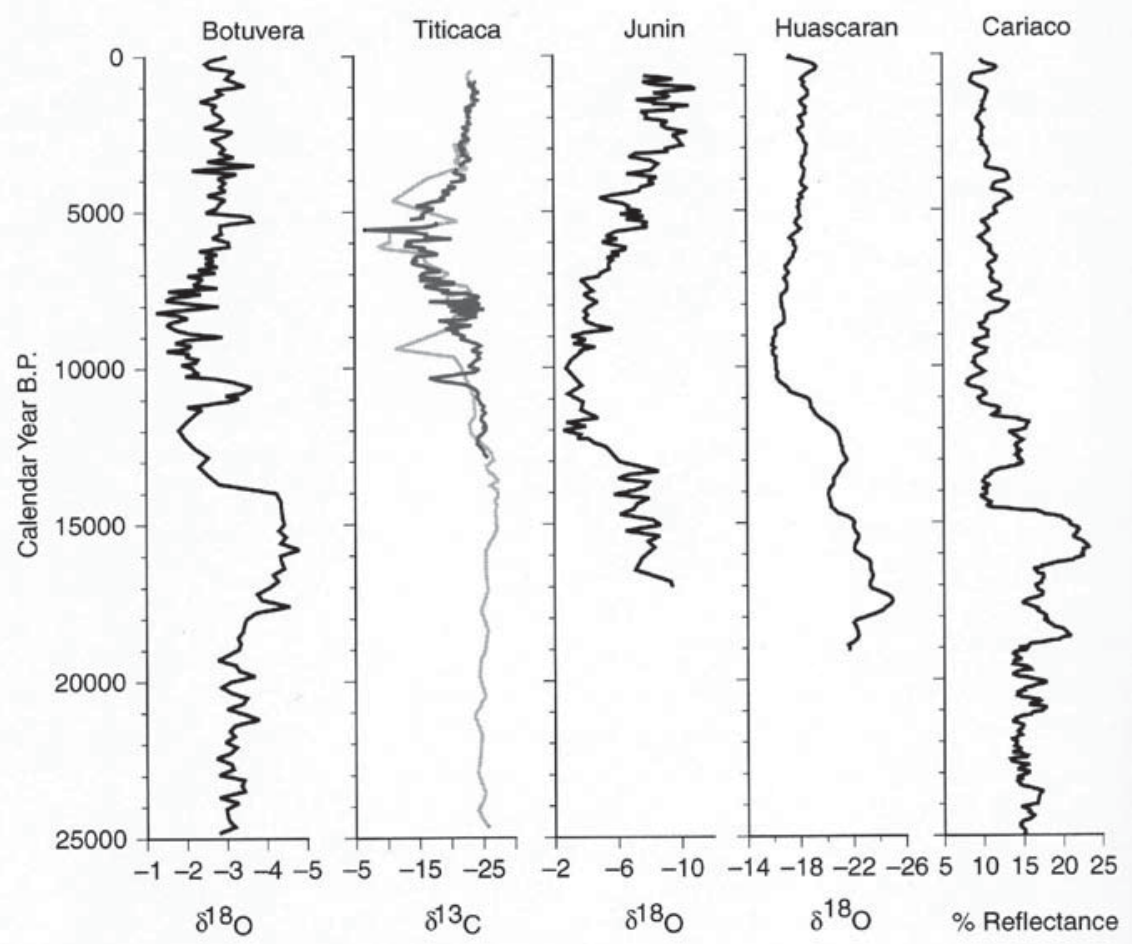

Figure 1. Late Glacial to Holocene paleoclimate time series from selected sites in tropical South America. These records are described in more detail in the text. All figures (with the exception of Cariaco) are aligned with wetter conditions to the right and drier conditions to the left. From left to right, data are the Botuverá speleothem record (Cruz et al. 2006); Lake Titicaca carbon isotopes of organic carbon (Bakert al. 2001a, 2005); Lago Junin oxygen isotopes in carbonate sediments (Seltzer et al. 2000); Huascaran oxygen-isotopic values (Thompson et al. 1995); Cariaco reflectance in sediments (Peterson et al. 2000). In general, relatively wet (dry) conditions prevailed in the southern (northern) tropics during the Last Glacial Maximum and the late Holocene, and relatively dry (wet) conditions prevailed in the southern (northern) tropics during the early and mid Holocene.

solation, thus, it is no surprise that insolation variability is capable of forcing large changes in precipitation amount. Throughout the tropics, it is almost universally observed that $\delta^{18} \mathrm{O}$ of precipitation is a measure of the amount of "rain out" from the atmosphere of moisture along its advective pathway from the evaporation source to the site of precipitation (e.g. Dansgaard 1964, Rozanski et al. 1993, Vuille et al. 2003a, Vimeux et al. 2005). Although changing circulation trajectories and changing moisture sources can surely complicate its interpretation, we accept that $\delta^{18} \mathrm{O}$ in past precipitation, derived either from its direct measurement in ice cores or less direct deduction from measurements in speleothems or lacustrine carbonates, is a valid proxy for past precipitation amount. Thus, the nearly exact correspondence between stable oxygen isotopic variations recorded by speleothem carbonates from Botuverá cavern in the 
southern subtropics of Brazil $\left(27^{\circ} \mathrm{S}\right)$ and summer insolation for the past 116,000 years (Cruz et al. 2006), is strong confirmation that summer insolation is a major control on South American summer monsoonal precipitation, thus, total annual precipitation.

On sub-orbital time-scales, several studies have shown that throughout the southern South American tropics, precipitation amount is elevated during North Atlantic cold events (Baker et al. 2005). Again the speleothem records illustrate this best for the late Pleistocene. For the past 210,000 years, speleothem growth, signifying wet conditions, observed in a cave in the Nordeste of Brazil at $10^{\circ} \mathrm{S}$, occurred only during North Atlantic cold events (Wang et al. 2004). Farther south at Botuverá cavern, Cruz and co-workers $(2006,2007)$ noted negative departures of $\delta^{18} \mathrm{O}$, signifying increased precipitation, coincident with each of the last 10 Heinrich events and the Younger Dryas. The precise anticorrelation at millennial time-scales between the late Pleistocene $\delta^{18} \mathrm{O}$ records of Botuverá cavern in the South American monsoon and Hulu cave located in the Asian monsoon (Wang et al. 2006) is a remarkable paleoclimate result and supports the proposed relationship between subtropical South American precipitation increases and both northern monsoon dry periods and North Atlantic cold events.

There are surprisingly few high-resolution Holocene-age paleoclimate records in tropical South America. Three of particular interest are from the Cariaco Basin off the north coast of Venezuela (Black et al. 1999, 2004, Haug et al. 2001, 2003, Peterson et al. 2000, Peterson and Haug 2006), Laguna Pallcacocha in the southern Ecuadorian Andes (Rodbell et al. 1999, Moy et al. 2002), and the Quelccaya ice core from the Cordillera Oriental of southern Peru (Thompson et al. 1985).

Laguna Pallcacocha is thought to be primarily a record of ENSO variability and amplitude, in which individual El Niño events are recorded by alluvial deposition into the lake basin (Rodbell et al. 1999). Although Laguna Pallcacocha records some variability at millennial timescales, the climatic interpretation of this variability is not clear. Moy and co-workers (2002) suggest two alternatives: millennial variability may be related to North Atlantic cold events (Bond et al. 2001) or may be somehow intrinsic to ENSO.

The Quelccaya ice core record (Thompson et al. 1985) is one of the most valuable tropical South American paleoclimate archives, because it preserves ice layers that have been accurately annualized to at least 500 year BP. The climatic interpretation of Quelccaya has been controversial, however, with disagreement arising about the fidelity of the annual accumulation data (e.g. Hastenrath et al. 2004, Vimeux et al. 2008) and the climatic significance of the stable oxygen isotopic ratios (Thompson et al. 2000, Vuille et al. 2003a,b, Hoffmann et al. 2003, Hastenrath et al. 2004, Vimeux et al. 2005, Sturm et al. 2007). We accept the standard interpretation mentioned previously (Dansgaard 1964, Rozanski et al. 1993), that $\delta^{18} \mathrm{O}$ of tropical precipitation is largely a measure of the amount of precipitation rainout between source (the Atlantic Ocean and the Amazon) and the final sink (Quelccaya). Thus, the isotopic record of Quelccaya, like that of Botuverá cave, is a regional-scale measure of past precipitation. 
Perhaps the most salient feature of the Quelccaya $\delta^{18} \mathrm{O}$ record is its highly significant and persistent, decadal-scale (12-14 years) variability and the correlation of that variability with the low-frequency variability of tropical North Atlantic SST (Melice and Roucou 1998). This study implies that for the past half millennium there has been significant quasi-periodic, decadal variability of precipitation amount over southern tropical South America, and this precipitation has varied inversely with tropical North Atlantic SST on decadal timescales.

The Cariaco sediment record indicates that the northern tropics of South America were dry during North Atlantic cold events throughout the entire last glacial and the Holocene (Figure 1), including the Younger Dry as and the Little Ice Age (Peterson et al. 2000, Haug et al. 2001). Peterson and Haug (2006) illustrated the similarity over the last several centuries between the time series of titanium concentrations in Cariaco sediments (a well-established proxy measure of runoff from northern continental South America) and the Quelccaya $\delta^{18} \mathrm{O}$ record indicating that even at decadal-to-multidecadal timescales precipitation in northern and southern tropical South America was anti-phased and correlated with North Atlantic SST.

\section{Reconstruction of Holocene Precipitation in the Northern Altiplano, Lago Umayo, Peru}

Many of the studies discussed previously have endeavored to reconstruct a history of precipitation with high temporal resolution. However, none of these studies actually quantify the amount of past precipitation. In this section, we present new chemical, stable isotopic, and paleobiotic data determined on a lacustrine sediment core, and we advance a original methodology for calculation of mean annual precipitation. We apply this method to produce a ca. 7000 yearlong, high-resolution (sub-decadal, on average) record of precipitation in the southern tropical Andes of Peru. Here we again caution that our results depend upon simplifying assumptions that are difficult to test. Thus our precipitation reconstruction should be considered to be tentative.

\subsection{Regional Setting of Lago Umayo}

Lago Umayo $\left(15.44^{\circ} \mathrm{S}, 70.10^{\circ} \mathrm{W}, \sim 3880 \mathrm{masl}\right)$ is located just to the west of Lake Titicaca, approximately $17 \mathrm{~km}$ northwest of the city of Puno, Peru (Figure 2). Two main rivers, the Rio Vilque and Rio Challamayo, flow into the lake, and the lake drains via the Rio Ilpa into Lake Titicaca. The watershed area is approximately $975 \mathrm{~km}^{2}$. Lago Umayo has a surface area of about $40.0 \mathrm{~km}^{2}$ not including the island in its center that occupies $1.05 \mathrm{~km}^{2}$. No bathymetric charts of the lake have been published; the greatest depth of the lake is over $20 \mathrm{~m}$.

Temperature and precipitation data, recorded by SENAMHI, Peru, are available for Puno, Peru, from two stations Salcedo $\left(15.88^{\circ} \mathrm{S}, 70.00^{\circ} \mathrm{W}, 3840\right.$ masl) and Puno $\left(15.83^{\circ}, 70.01^{\circ}, 3812\right.$ masl) that together span the period from 1932 to the present. 


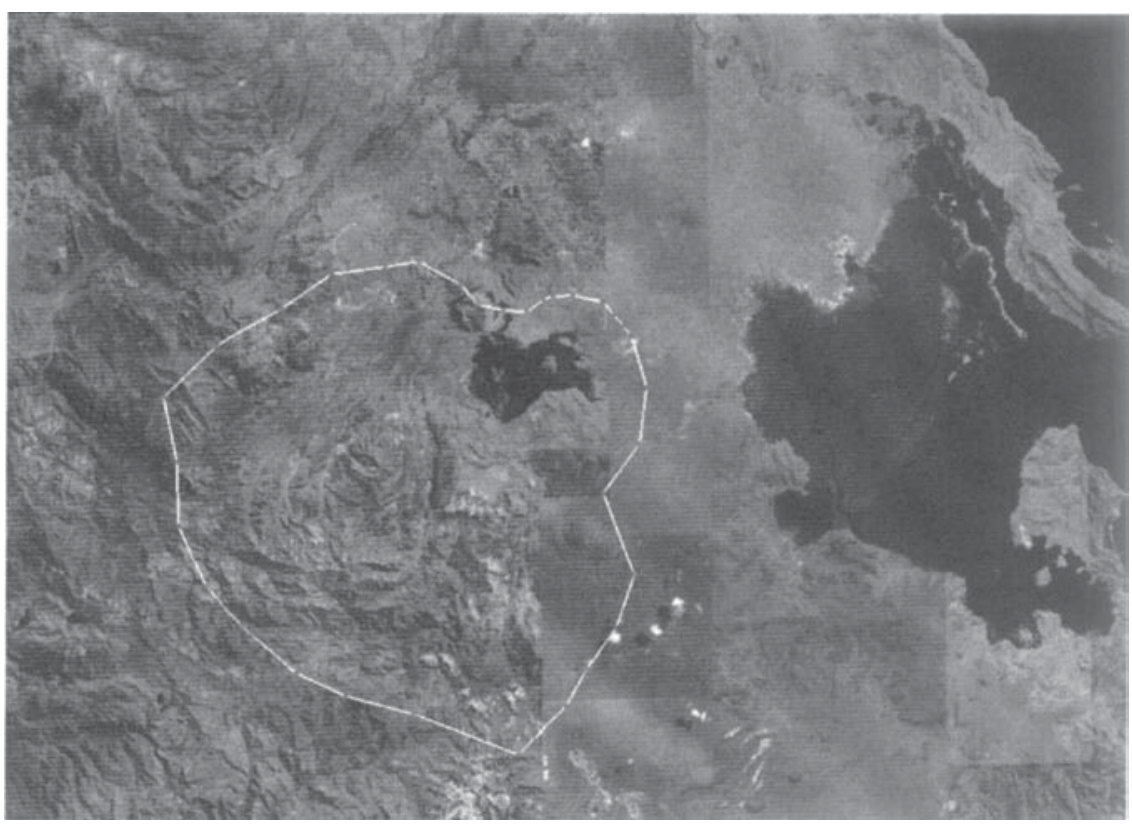

Figure. 2. Lago Umayo watershed in white outline. The image is from Google Earth and has dimensions of $85 \mathrm{~km}(\mathrm{E}-\mathrm{W})$ and $60 \mathrm{~km}(\mathrm{~N}-\mathrm{S})$.

Mean annual precipitation (MAP) for the period 1960-1990 was $717 \mathrm{~mm}$ at Puno and $753 \mathrm{~mm}$ at Salcedo (INTECSA 1993). Mean annual temperature (MAT) for $1960-1990$ was $8.5^{\circ} \mathrm{C}$ at Puno and $8.4^{\circ} \mathrm{C}$ at Salcedo. At both stations, $87 \%$ of MAP occurs during the wet half-year of November through April. The driest year on record was 1940/41. Other dry years were 1965/6, 1982/3,1991/2, and $1997 / 9$. Three of these $(40 / 41,82 / 83$, and 97/98) were El Niño years, but the other two (65/66 and 91/92) were years of an essentially "neutral" Pacific. The decade from 1936 to 1945 is noteworthy, because precipitation was significantly below normal for these consecutive ten years.

Spatial gradients exist in the regional precipitation and temperature fields. In general, precipitation totals and temperatures decrease with increasing distance (and often increasing elevation) from Lake Titicaca. Compared to Puno and Salcedo on the shore of Lake Titicaca, MAP for the period 1960-1990 was $599 \mathrm{~mm}$ at Juliaca $\left(15.5^{\circ} \mathrm{S}, 70.2^{\circ} \mathrm{W}, 3825 \mathrm{masl}\right)$ about $25 \mathrm{~km}$ west of Lake Titicaca and $648 \mathrm{~mm}$ at Umayo. Lago Umayo is approximately midway between Juliaca and Puno, approximately $12 \mathrm{~km}$ west of Lake Titicaca.

Because of the tropical, high-altitude setting of the region, the diurnal temperature range is far greater than the seasonal temperature range. For example, at Juliaca the mean monthly diurnal temperature range is $17.8^{\circ} \mathrm{C}$ and at Puno it is $11.7^{\circ} \mathrm{C}$ (because of its closer proximity to the moderating influences of Lake 
Titicaca), whereas the total annual range of mean monthly temperatures at Juliaca is $5.9^{\circ} \mathrm{C}$ (coldest month is July, warmest is December) and at Puno it is only $4.3^{\circ} \mathrm{C}$. The mean annual value of relative humidity at Puno is $49 \%$. The highest mean monthly values of relative humidity occur in wet season: $>60 \%$ from January through March. The lowest mean monthly values of relative humidity occur in dry season: $<45 \%$ from May through October. Although top-of-atmosphere (TOA) radiation is significantly greater in the summer than in the winter, the greater cloudiness of the summer wet season cancels much of this intra-annual variation. The Penman equation yields values of potential evapo-transpiration in reasonable agreement with observed values in the Titicaca watershed (INTECSA 1993), even in the absence of wind, humidity, and solar radiation data (Garcia et al. 2004).

The level of the surface of Lake Titicaca has been measured at Puno since 1915 (SENAMHI, Peru). This level fluctuates by about $1 \mathrm{~m}$ each year, rising following the wet season of peak riverine input and falling more steadily throughout the year due to evaporative loss from the lake surface and (much less) outflow into the Rio Desaguadero. On inter-annual timescales, the level of the lake has varied by about $6 \mathrm{~m}$, attaining a recorded high of 3812.48 masl in 1986 following three anomalously wet years and a recorded low of 3806.26 masl in 1943 as a result of extended drought. The value of the lake-level time series as a measure of effective moisture and wet season precipitation has been discussed in several previous studies (including Melice and Roucou 1998, Baker et al. 2001a, Hastenrath et al. 2004). Here we utilize lake-level rise from October to March of the following year (the wet season spans the calendar year) as a regional measure of the wet season precipitation amount.

The Quelccaya ice core as an archive of past climate is particularly relevant to our present study because its location $\left(13.9^{\circ} \mathrm{S}, 70.8^{\circ} \mathrm{W}, 5670 \mathrm{masl}\right)$ is just to the north of the Lake Titicaca watershed about $200 \mathrm{~km}$ north of our study site. The inverse correlation between the annual $\delta^{18} \mathrm{O}$ measurements of Quelccaya and the total wet season precipitation for the same year in Puno is significant at the

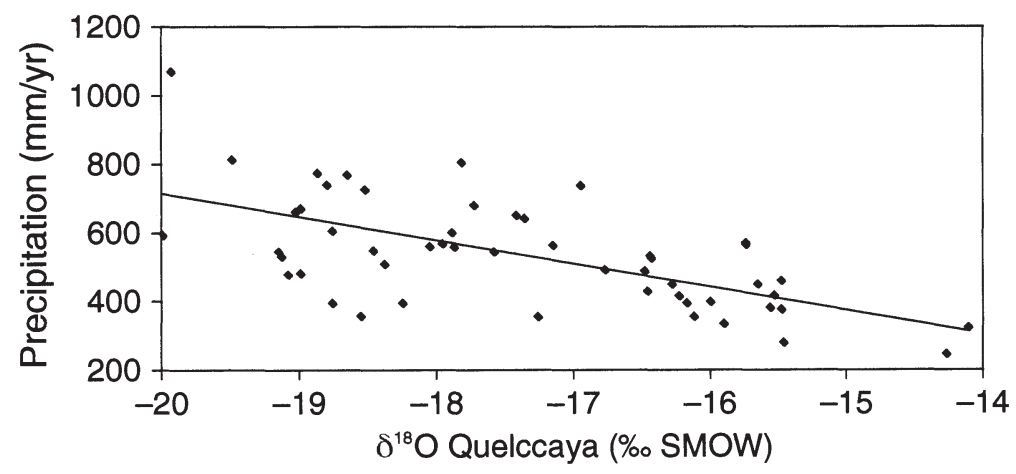

Figure 3. Wet season (November-April) precipitation in Puno is inversely correlated with $\delta^{18} \mathrm{O}$ of ice of the same year from Quelccaya $\left(n=66, r^{2}=0.403, p<0.001\right)$. 


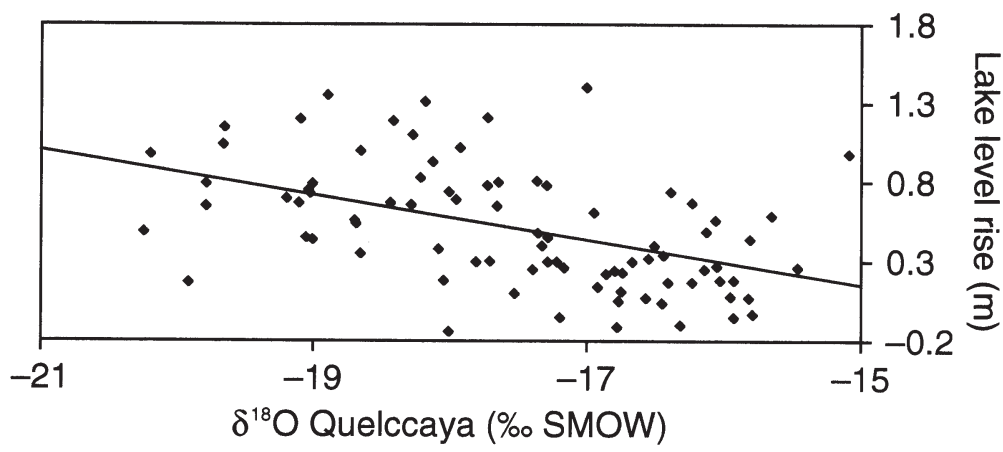

Figure 4. The stable isotopic composition of Quelccaya ice core (Thompson et al. 2006) is significantly inversely correlated with the lake level rise of Lake Titicaca from October of the preceding year to March of the same year $\left(r^{2}=0.2393, n=85, p<0.001\right)$.

99.9\% level (Figure 3, $\mathrm{r}^{2}=0.403$ ). If we compare the annual $\delta^{18} \mathrm{O}$ measurements of Quelccaya to the October-March rise of Lake Titicaca for the same year (Figure 4), again the inverse correlation is highly significant $\left(r^{2}=0.239\right)$. The latter correlation would likely be higher except for a discrepancy between the $\delta^{18} \mathrm{O}$ values of the different Quelccaya cores (Thompson et al. 2006). We speculate that the discrepancy may arise from dating errors of \pm 1 year. Thus, when we compute 5-year moving averages of the $\delta^{18} \mathrm{O}$ and lake level records (Figure 5), the correlation between the two time series improves $\left(\mathrm{r}^{2}=0.686\right)$. Vimeux and co-workers (2005) demonstrated that $\delta \mathrm{D}$ values of precipitation from the nearby Zongo Valley, Bolivia, correlate even more highly with rainout over the "upstream" Amazon basin.

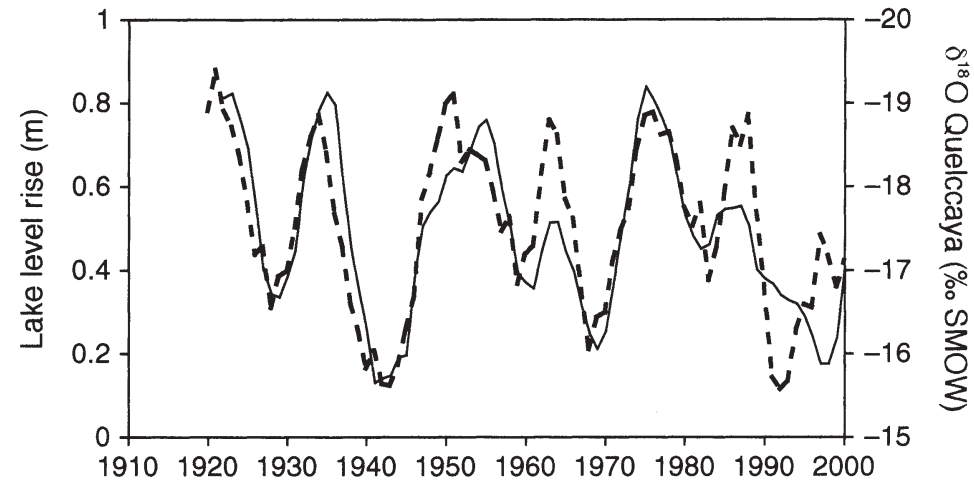

Figure 5. Five-year moving averages of the time series (1915-2000) of $\delta^{18} \mathrm{O}$ Quelccaya (solid line, data from Thompson et al. 2006) and lake level rise of Lake Titicaca (dotted line). Note that the $\delta^{18} \mathrm{O}$ scale is reversed such that more depleted values plot with a lake-level rise of greater magnitude $\left(r^{2}=0.686, \mathrm{n}=81, \mathrm{p}<0.001\right)$. 


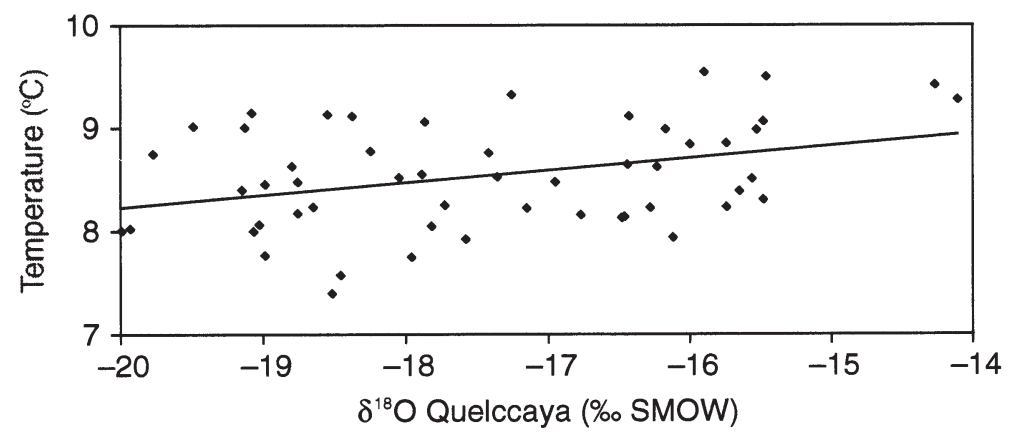

Figure 6. Mean annual temperature (July-June) in Puno is positively correlated with $\delta^{18} \mathrm{O}$ of ice of the same year from Quelccaya $\left(n=53, r^{2}=0.125, p<0.05\right)$.

Our findings agree with the conclusion of Hastenrath et al. (2004) that negative departures of $\delta^{18} \mathrm{O}$ in Quelccaya ice are accompanied by large-scale circulation departures that favor more abundant precipitation over the southern tropical Andes: from a paleoclimate perspective we conclude that $\delta^{18} \mathrm{O}$ is a reasonable predictor of precipitation amount in the southern tropical Andes and the adjacent Amazon basin. Previously, it has been assumed that $\delta^{18} \mathrm{O}$ in Quelccaya ice was inversely correlated with regional temperature (as it is in high latitude ice cores), thus negative departures of $\delta^{18} \mathrm{O}$ from mean values were taken to indicate periods of below-normal temperature. In fact, there is a positive, but only weakly significant, correlation between mean annual temperature in Puno and $\delta^{18} \mathrm{O}$ in Quelccaya ice (Figure 6).

\subsection{Methods}

Overlapping sediment cores were taken in 2001 in the eastern part of the lake in $\sim 10.5 \mathrm{~m}$ water depth using a Russian peat corer. The lithology of each core segment was described in the laboratory, and a $7.07 \mathrm{~m}$ composite core sequence was constructed from the overlapping drives based on visual correlation of distinctive sedimentary features. The composite core sequence was sampled continuously at $1-\mathrm{cm}$ resolution for diatom enumeration and stable carbon and oxygen isotopic composition of the carbonate fine fraction $\left(\mathrm{CaCO}_{3}\right.$ content of the sediments ranged from 28 to $100 \mathrm{wt} \%$ with a mean (SD) of $68.3(10.2) \mathrm{wt} \%$.).

Prior to isotopic analysis, all recognizable coarse shells and shell fragments were hand-picked from the dried sediment sample. The stable oxygen and carbon isotopic compositions of calcium carbonate in the fine fraction of the sediment were analyzed with an on-line, automated, carbonate preparation system linked to a Finnigan Delta XL ratio mass spectrometer in the Department of Geosciences at University of Massachusetts. Ratios are reported relative to the PDB standard. The reproducibility for the $\delta^{18} \mathrm{O}$ and $\delta^{13} \mathrm{C}$ determinations of standard materials is respectively $0.08 \%$ and $0.05 \%$. 
Sediments for diatom analysis were prepared following standard methodology (Battarbee 1986). A weighed aliquot of sediment was chemically digested with cold $10 \%$ hydrochloric acid and hydrogen peroxide to remove carbonate and organic material, respectively. Cleaned material was settled onto cover slips, dried, and mounted using Zrax, a high refractive-index diatom mounting material. Diatom valves were identified using differential interference contrast on a Zeiss Axioskop microscope with an oil immersion objective. At least 300 valves were counted per slide, and species abundances are expressed as a percentage of the total number of identified diatom valves. Diatom species were categorized as freshwater or saline and as planktic or benthic, based on known ecological affinities (Servant-Vildary and Roux 1990, Sylvestre et al. 2001, Tapia et al. 2003).

A chronology for the core was constructed using 10 accelerator mass spectrometry ${ }^{14} \mathrm{C}$ dates. ${ }^{14} \mathrm{C}$ dates were calibrated using CALIB 5.0.2 (Stuiver and Reimer 1993) using the Southern Hemisphere calibration (McCormac et al. 2004). The age-depth relationship was constructed by fitting a fifth-order polynomial through the calibrated ages (see Ekdahl et al. 2008 for more detailed information on age model construction).

\subsection{The Oxygen Isotopic Model}

The stable oxygen isotopic composition of a through-flow lake at hydrologic and isotopic steady state is given by Gat (1995):

$$
\delta_{\text {lake }}=\delta_{\mathrm{i}}+\left[(1-\mathrm{h})\left(\varepsilon^{*}+\mathrm{C}_{\mathrm{k}}\right)\right] /\left[\mathrm{h}+(1-\mathrm{h})\left(\mathrm{Q}_{\mathrm{i}} / \mathrm{Q}_{\mathrm{e}}\right)\right]
$$

where:

$\delta_{i} \quad$ is the stable oxygen isotopic composition of the influx and is assumed to have the same value as precipitation, $\delta_{\mathrm{P}}(\%$, $\mathrm{SMOW})$;

$\varepsilon^{*} \quad$ is the temperature-dependent oxygen isotopic separation factor for the equilibrium between water liquid and water vapor (\%o);

$\mathrm{C}_{\mathrm{K}}=14.2(\%)$ is a constant associated with kinetic fractionation during the non-equilibrium evaporation of water (Vogt 1978);

$\mathrm{h}$ is fractional relative humidity;

$\mathrm{Q}_{\mathrm{i}}$ is the flux of water into the lake from direct precipitation and river runoff $\left(\mathrm{m} \mathrm{a}^{-1}\right)$ normalized to the surface area of the lake;

$$
\mathrm{Q}_{\mathrm{i}}=\mathrm{P}+\mathrm{Pf}\left(\mathrm{S}_{\mathrm{W}} / \mathrm{S}_{\mathrm{L}}\right) \text {, where: }
$$

$\mathrm{P}$ is the precipitation rate $\left(\mathrm{m} \mathrm{a}^{-1}\right)$, assumed constant throughout the watershed;

$S_{W} / S_{L}$ is the ratio of the surface area of the watershed to the surface area of the lake;

$\mathrm{f}$ is the fraction of precipitation falling on the land that contributes to runoff (the remainder is assumed to be returned to the atmosphere 
by non-fractionating evapotranspiration);

$Q_{e}$ is the evaporative flux of water vapor from the lake surface to the atmosphere $\left(\mathrm{m} \mathrm{a}^{-1}\right)$, again normalized to the surface area of the lake.

In order to apply our model to the paleoclimate of the Umayo watershed, we assume constant values for $h, f, Q_{e^{\prime}} S_{L} / S_{W^{\prime}}$ and surface air temperature $T$. These are determined from present-day values of mean annual climatology (in the case of $h, Q_{e^{\prime}} f$, and $T_{A}$ ) or hypsometry (for $S_{L} / S_{W}$ ). The surface water temperature of the lake $\mathrm{T}_{\mathrm{W}}$ is assumed to be $2 \mathrm{~K}$ warmer than the surface air temperature $\mathrm{T}_{\mathrm{A}^{\prime}}$ similar to the difference observed at nearby Lake Titicaca (Carmouze 1992). $\varepsilon^{*}$ is a known function of $T_{W}$ (Kelvin), and here we use the formulation of Majoube (1971) to determine its value:

$$
\ln \alpha_{1-\mathrm{v}}=1137 \mathrm{~T}_{\mathrm{W}}^{-2}-0.4516 \mathrm{~T}_{\mathrm{W}}^{-1}-0.00207
$$

where $\alpha_{1-v}$ is the equilibrium isotopic fractionation factor between water liquid and water vapor and is related to $\varepsilon^{*}$ by:

$$
\varepsilon^{*}=1000(\alpha-1)
$$

We use the equation of $\mathrm{O}^{\prime} \mathrm{Neil}$ et al. (1969) to determine values for $\delta_{\text {lake }}$ from stable isotopic analysis of the fine fraction of the carbonate sediments $\delta_{c}$ :

$$
\delta_{\text {lake }}=\delta_{c}-2.78 \times 10^{6} \mathrm{~T}_{\mathrm{W}}^{-2}-2.89
$$

Finally, following the discussion of the previous section, we use our observed relationship between precipitation amount and stable isotopic composition of precipitation to write an expression for $\delta_{\mathrm{P}}=\delta_{\mathrm{i}}$ :

$$
\delta_{i}=-14.126 P-7.317
$$

Substituting into (1) and rearranging, we can solve the quadratic equation for precipitation that depends only on temperature and $\delta_{\text {lake }}$ (Figure 7 ).

In order to improve upon our present approach, it will be most important to quantitatively reconstruct (1) water paleo-temperature and (2) evaporative flux, using only variables that can be realistically deduced from the paleoclimate record. Delclaux and co-workers (2007) recently determined that the Abtew model of evaporation, containing net solar radiation as its only climate variable, produced an excellent fit with instrumental data on the evaporative flux from the surface of Lake Titicaca.

How appropriate is it to use a steady-state model (1) to deduce past climate? In brief, to our knowledge hydrologic steady-state $(\mathrm{dV} / \mathrm{dt}=0$, the volume of the lake remains unchanged through time) is today maintained in Lago Umayo with only minor changes in its lake level from year-to-year. Our sedi- 


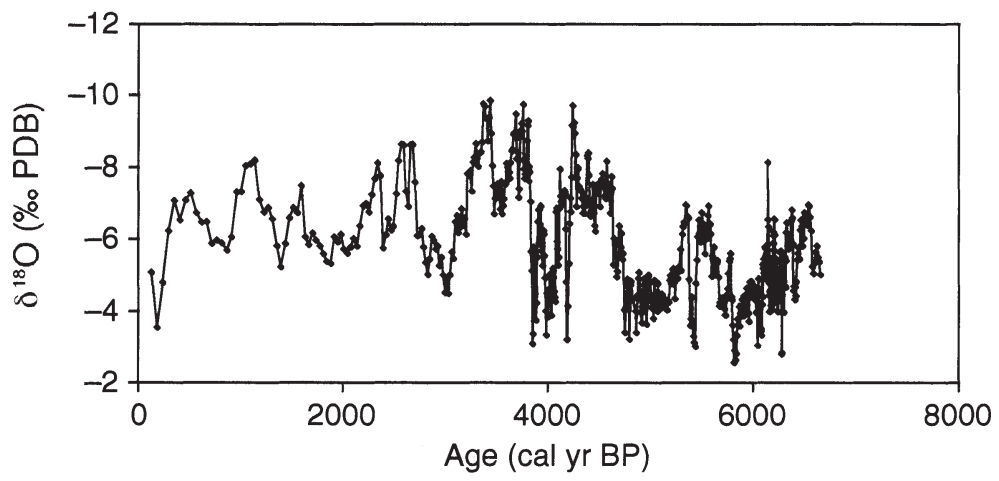

Figure 7. Stable oxygen isotopic composition of carbonate fine fraction of Lago Umayo. Note that the $\delta^{18} \mathrm{O}$ axis is reversed such that enriched values plot lower on the axis.

mentological analysis indicates no unconformities during the period of the record, that is the lake level certainly never fell by more than $10 \mathrm{~m}$ even when the lake was apparently closed (in the early Holocene). The diatom evidence presented below supports the argument that since the middle Holocene the lake has been relatively fresh and overflowing, thus near its present volume. The stable isotopic evidence itself, specifically the low rate of $\delta^{18} \mathrm{O}$ change (on order of $0.02 \% \mathrm{a}^{-1}$ ), argues that the assumption of isotopic steady-state is also valid for our application.

\subsection{Model Results and Validation}

Our first attempt at the quantitative isotopic reconstruction of precipitation (Figure 8) spans 6529 years of record from 6656 to 127 cal year BP. The reconstructed long-term mean annual precipitation is $600 \pm 130( \pm 2 \sigma) \mathrm{mm} \mathrm{a}^{-1}$. Precipitation increased about $12 \%$ over the duration of the record from the early Holocene to near modern. But this increase was neither linear nor gradual, rather it occurred abruptly at about $4750 \mathrm{cal}$ year BP. A second attribute of the precipitation time series is its large-amplitude variability. Thus, over the portion of the record from 6656 to 3000 cal year BP where the resolution is highest, averaging 6.5 year/sample, there are about 15 events with amplitude $>1 \sigma$, an average frequency of about 240 year and an average duration of about 100 years. The largest amplitude events between 5000 and 3000 year BP were $\sim 15 \%$ positive or $\sim 15 \%$ negative departures of mean annual precipitation from the prevailing mean, often sustained over two to three centuries. These large sustained changes of precipitation would have had a major impact on the natural biota and early human occupants of the region. For reference, our analysis of data from the United Nations Food and Agriculture Organization (FAO; not shown) indicates that modern agricultural yields of quinoa and potatoes on the Alti- 


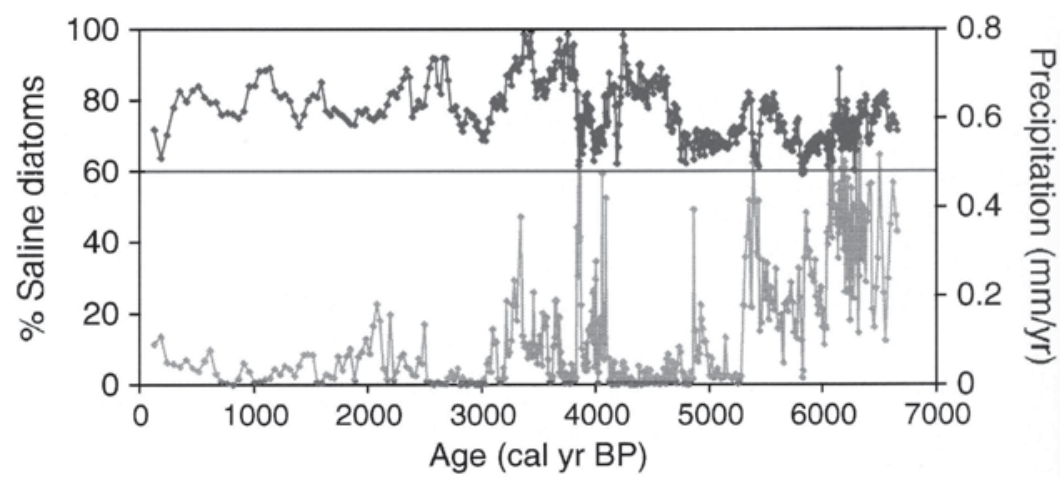

Figure 8. Time series of the mean annual precipitation (black line and diamonds) calculated from the isotopic analysis of carbonate sediments from Lago Umayo. Also shown are abundances of saline diatoms as a percentage of the total diatom assemblage (gray line and diamonds) (See Ekdahl et al. 2008 for complete species compositional data). The black horizontal line represents closed basin lake conditions: when precipitation falls below $480 \mathrm{~mm} \mathrm{a}^{-1}$, Lago Umayo becomes a closed basin lake and its salinity rises. This calculation of precipitation assumed constant relative humidity of 0.5 and constant air temperature of $8.0^{\circ} \mathrm{C}$ (see text for more details).

plano are adversely impacted by this magnitude of climate anomaly even if sustained for only one summer.

At times in its past, Lago Umayo was a closed basin, and there was no outflow into its only outlet, the Rio Ilpa. These endorheic conditions took place during periods of negative water balance, most likely due to lower precipitation. As long as closed-basin conditions persisted, the soluble constituents of inflowing rivers and direct precipitation accumulated in the lake, and the salinity of the lake rose. Our isotopic model is an easy way to identify the timing of these closed-basin, dry phases. Thus, given closed basin conditions $Q_{i}=Q_{e}$ and equation (1) simplifies to:

$$
\delta_{\text {lake }}-\delta_{\mathrm{i}}=(1-\mathrm{h})\left(\varepsilon^{*}+\mathrm{C}_{\mathrm{K}}\right)
$$

The rate of increase of the salinity of the lake is easily estimated by assuming constant salt content of the tributary rivers. Because all of this salt remained in the lake during the closed basin period, the salt content of the lake would have increased at roughly $15 \mathrm{mg} \mathrm{l}^{-1} \mathrm{a}^{-1}$. Within a century of the lake becoming (and remaining) closed, its salinity would have increased to about $1.5 \mathrm{~g} \mathrm{l}^{-1}$ (in addition to its original salt content), well within the salinity optimum of the dominant saline diatoms. In fact, the measured abundances of saline diatoms demonstrate exactly the expected response (Figure 8). During periods when the calculated mean annual precipitation was sustained at a value near that calculated for closed-basin conditions, the abundance of saline diatoms increased rapidly. During subsequent periods of increased precipitation, flushing and freshening of the lake led to decreased abundances of saline diatoms. The agreement between the saline diatom abundance data and the carbonate isotope data provides strong independent confirmation for our methodology. 


\section{Discussion}

With few exceptions (e.g. Baker et al. 2005, Ekdahl et al. 2008), the forcing of Holocene climate variability in the southern tropics of South America has previously been ascribed to orbital and ENSO mechanisms. Indeed, as introduced previously, it is clear that insolation forcing of the South American summer monsoon is largely responsible for the early Holocene drier climate and late Holocene wetter climate of the region. And on inter-annual timescales, it is likely that ENSO variability played a role in forcing past precipitation variability in the southern tropics much as it does today (e.g. Rodbell et al. 1999, Moy et al. 2002, Bradley et al. 2003, Theissen et al. 2008). But, as we have shown (Figure 8), between these orbital and inter-annual timescales, there is large amplitude precipitation variation at decadal-to-centennial-to-millennial timescales. We believe that much of this variation is forced by northern tropical Atlantic SST change, the plausibility of which is documented in both empirical (e.g. Nobre and Shukia 1996, Zeng et al. 2008) and modeling studies (Harris et al. 2008).

During the instrumental period, throughout most of the northern tropical Atlantic, SST is largely determined by surface ocean-atmosphere heat exchange (e.g. Yu et al. 2006), a significant portion of which is due to latent heat exchange driven by surface winds (e.g. Carton et al. 1996, Chang et al. 1997). In the boreal winter, coincident with the wet season in the southern tropics of South America, SST anomalies in the northern tropical Atlantic are significantly correlated with highlatitude North Atlantic SST anomalies (forming the North Atlantic SST tripole). These Atlantic SST anomalies co-vary with the atmospheric North Atlantic Oscillation (e.g. Seager et al. 2000) at its characteristic decadal-scale periodicity (Hurrell and van Loon 1997). These relationships suggest the possibility that on longer timescales, low temperatures in the high-latitude North Atlantic accompanied by high surface pressures in the Bermuda High and stronger northeasterly trades, can cause anomalously cold SSTs in the tropical North Atlantic and a southward shift of the mean annual position of the ITCZ. The anomalously strong northeasterly trades should also bring about increased moisture convergence in the Amazon Basin and increased precipitation in the southern tropics of South America, including much of the Amazon and tropical Andes. In fact, Curtis and Hastenrath (1999), examining reanalysis data from 1958 to 1997, documented an example of such a long-term increase of the Atlantic northeasterly trades that supported a long-term increase in moisture convergence in the Amazon region. The trend observed by Curtis and Hastenrath (1999) also coincided with a nearly 40 year period of increasing winter NAO index (Hurrell and Van Loon 1997).

In agreement with this hypothesized mechanism, the centennial-scale wet periods that we reconstruct at Lago Umayo, correlate reasonably well with North Atlantic cold periods reconstructed by Bond et al. (2001) in the North Atlantic (Figure 9). We believe that the lack of a more perfect correlation between these two time series is due to problems in the age models of both records.

We can also reconstruct past precipitation amount from southern tropical Andean ice core records if we assume, as we have done in this study, a constant 


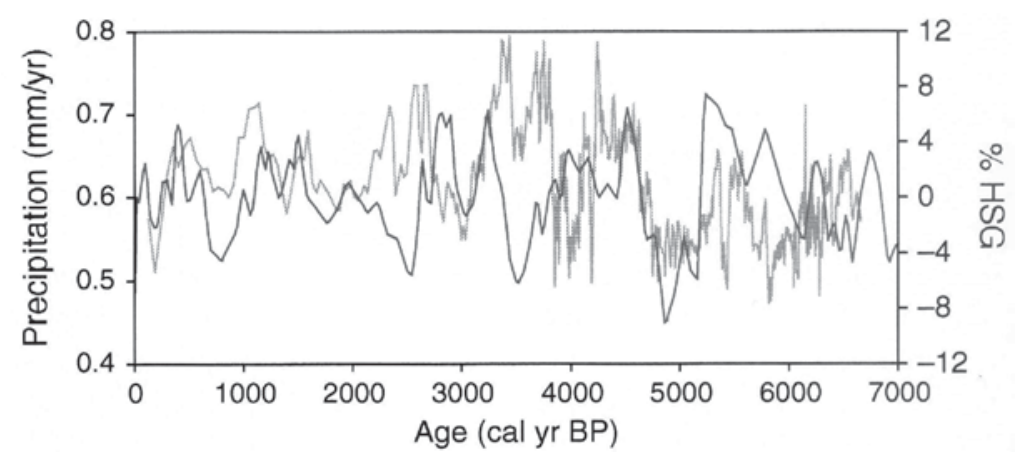

Figure 9. Altiplano precipitation (gray line) and hematite-stained grains (HSG) in the North Atlantic (black line). Their reasonable correspondence supports the hypothesized role of North Atlantic SST in forcing Altiplano precipitation. HSG data are from Bond et al. (2001).

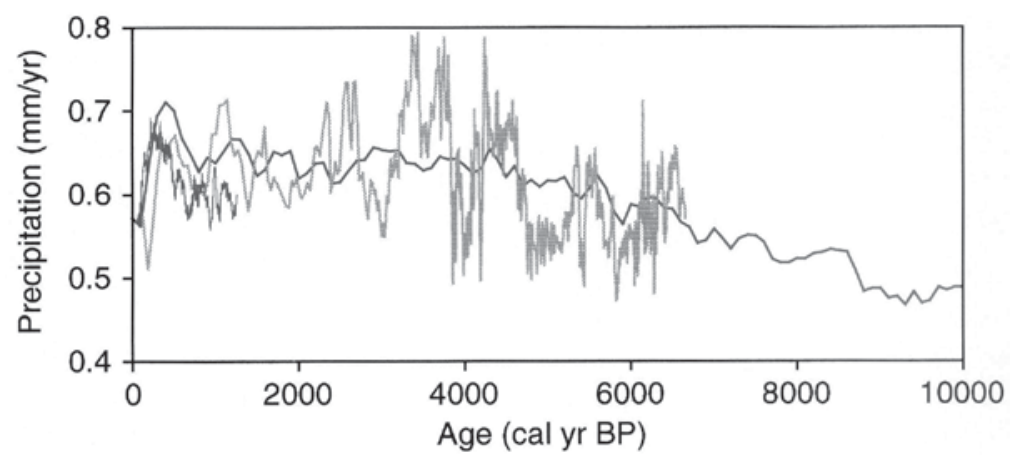

Figure 10. Time series of wet-season precipitation reconstructed from Quelccaya ice core (black line, 50-year moving average, Thompson et al. 1985), Huascaran ice core (low-resolution curve, black line, centennial averages, Thompson et al. 1995), and Lago Umayo sediments (gray line).

relationship between local precipitation and its isotopic composition. Using this approach, precipitation determined from both the Quelccaya and Huascaran ice cores (Figure 10) agrees reasonably well with that from Lago Umayo. The Huascaran data are reported as centennial averages (Thompson et al. 1995), thus they average out all higher-frequency variability. Furthermore, the age model for the Huascaran ice core is constructed without any absolute age dates for all of the Holocene with the exception of the last century.

\section{Conclusions}

Atlantic variability is not a dominant factor in forcing the climate of tropical South America during most of the instrumental period, but with few exceptions (e.g. 2005), over this interval, annual SST anomalies are relatively small. On 
multi-decadal to millennial time scales, past SST anomalies were much larger and therefore might have played a much larger role in forcing climate variability. We reviewed a number of paleoclimatic time series from continental South America, as well as climate model simulations, that support a significant influence of Atlantic SST variation on precipitation in tropical South America during the late Quaternary.

Our reconstruction of precipitation at decadal scale over the last $\sim 7000$ years from the oxygen isotopic composition of carbonates in lake sediments in the northern Altiplano of the southern tropical Andes, is consistent with previous regional reconstructions that show a secular increase in precipitation from the mid Holocene to the present day. Our quantitative reconstruction of this trend suggests a $\sim 12 \%$ increase in precipitation (from $\sim 560$ to $650 \mathrm{~mm} \mathrm{a}^{-1}$ ), coincident with the $6 \%$ increase in summer insolation at this latitude over the same period. The increase in precipitation was neither uni-directional nor gradual. Instead, every 240 years on average, precipitation increased or decreased by at least $\sim 8 \%$ for periods lasting on average 100 years. The largest of these events had $\sim 15 \%$ positive or negative departures from the long-term mean precipitation. These southern tropical wet events apparently occurred during periods when SSTs in the high-latitude North Atlantic were low, corroborating the hypothesis of an Atlantic SST control on tropical South American precipitation. Further testing of this hypothesis will require better-dated records of both Atlantic SST and of Andean or Amazonian precipitation.

\section{References}

Aceituno P, Montecinos A (1993) Circulation anomalies associated with dry and wet periods in the South American Altiplano. In: Fourth International Conference on Southern Hemisphere Meteorology and Oceanography, American Meteorological Society, Boston, MA

Arz HW, Patzold J, Wefer G (1998) Correlated millennial-scale changes in surface hydrography and terrigenous sediment yield inferred from Last-Glacial marine deposits off Northeastern Brazil. Quat Res 50:157-166

Baker PA, Seltzer GO, Fritz SC et al (2001a) The history of South American tropical precipitation for the past 25,000 years. Science 291:640-643

Baker PA, Rigsby CA, Seltzer GO et al (2001b) Tropical climate changes at millennial and orbital timescales on the Bolivian Altiplano. Nature 409:698- 700

Baker PA, Fritz SC, Garland J, Ekdahl E (2005) Holocene hydrologic variation at Lake Titicaca, Bolivia/Peru, and its relationship to North Atlantic climate variation. J Quat Sci 20: 655-662

Battarbee RW (1986) Diatom analysis. In: Berglund, B (ed.) Handbook of Holocene palaeoecology and palaeohydrology. Wiley, New York, pp 527-570

Berger A, Loutre MF (1991) Insolation values for the climate of the last 10 million years. Quat Sci Rev 10:297-317

Black DE, Peterson LC, Overpeck JT (1999) Eight centuries of North Atlantic ocean atmosphere variability. Science 286:1709-1713

Black DE, Thunell RC, Kaplan A et al (2004) A 2000-year record of Caribbean and tropical North Atlantic hydrographic variability. Paleoceanography 19:PA2022. doi:10.1029/2003PA000982

Bond G, Kromer B, Beer J et al (2001) Persistent solar influence on North Atlantic climate during the Holocene. Science 294:2130-2136 
Bradley RS, Vuille M, Hardy D, Thompson LG (2003) Low latitude ice cores record Pacific sea surface temperatures. Geophys Res Lett 30:doi:10.1029/2002GL016546

Broccoli AJ, Dahl KA, Stouffer RJ (2006) Response of the ITCZ to Northern Hemisphere cooling. Geophys Res Lett 33:L01702, doi:10.1029/2005GL024546

Carmouze JP (1992) The energy balance. In: Dejoux C, Iltis A (eds.) Lake Titicaca, a Synthesis of Limnological Knowledge. Kluwer, Dordrecht

Carton JA, Cao X, Giese BS, Silva AM (1996) Decadal and interannual SST variability in the tropical Atlantic Ocean. J Phys Oceanogr 26:1165-1175

Chang P, Ji L, Li H (1997) A decadal climate variation in the tropical Atlantic Ocean from thermodynamic air-sea interactions. Nature 385:516-518

Chiang JCH, Bitz CM (2005) Influence of high latitude ice cover on the marine Intertropical Convergence Zone. Clim Dyn 25:477-496

Chiang JCH, Koutavas A (2004) Tropical flip-flop connections. Nature 432:684-685

Cross SL, Baker PA, Seltzer GO, Fritz SC, Dunbar RB (2000) A new estimate of the Holocene lowstand level of Lake Titicaca, central Andes, and implications for tropical palaeohydrology. Holocene 10:21-32

Cruz FWJ, Burns SJ, Karmann I et al (2005) Insolation-driven changes in atmospheric circulation over the past 116,000 years in subtropical Brazil. Nature 434:63-66

Cruz FW, Burns SJ, Karmann I, Sharp WD, Vuille M (2006) Reconstruction of regional atmospheric circulation features during the late Pleistocene in subtropical Brazil from oxygen isotope composition of speleothems. Earth Planet Sci Lett 248:495-507

Cruz FW, Burns SJ, Jercinovic M et al (2007) Evidence of rainfall variations in Southern Brazil from trace element ratios $(\mathrm{Mg} / \mathrm{Ca}$ and $\mathrm{Sr} / \mathrm{Ca})$ in a Late Pleistocene stalagmite. Geochimica et Cosmochimica Acta 71:2250-2263

Curtis S, Hastenrath S (1999) Trends of upper-air circulation and water vapour over equatorial South America and adjacent oceans. Int J Climatol 19:863-876

Dansgaard W (1964) Stable isotopes in precipitation. Tellus 16:436-468

Delclaux F, Coudrain A, Condom T (2007) Evaporation estimation on Lake Titicaca: A synthesis review and modeling. Hydrol Process 21:1664-1677

Ekdahl E, Fritz SC, Baker PA et al (2008) Holocene multi-decadal to millennial-scale hydrologic variability on the South American Altiplano. Holocene 18:867-876

Fritz SC, Baker PA, Seltzer GO et al (2007) Quaternary glaciation and hydrologic variation in the South American tropics as reconstructed from the Lake Titicaca drilling project. Quat Res 68:410-420

Garcia M, Raes D, Alien R, Herbas C (2004) Dynamics of reference evapotranspiration in the Bolivian highlands (Altiplano). Agric For Meteorol 125:67-82

Garreaud RD, Vuille M, Compagnucci R, Marengo J (2008) Present-day South American climate. Palaeogeogr Palaeoclimatol Palaeoecol 281:180-195; doi: 10.1016/j.palaeo.2007.10.032

Gat JR (1995) Stable isotopes and the water balance of fresh and saltwater lakes. In: Lerman A, Imboden DM, Gat JR (eds.) Physics and chemistry of lakes. Springer-Verlag, Berlin

Harris PP, Huntingford C, Cox PM (2008) Amazon Basin climate under global warming: The role of the sea surface temperature. Phil Trans R Soc B 363:1753-1759

Hastenrath S, Greischar L (1993) Circulation mechanisms related to Northeast Brazil rainfall anomalies. J Geophys Res Atmos 98(D5):5093-5102

Hastenrath S, Polzin D, Francou B (2004) Circulation variability reflected in ice core and lake records of the southern tropical Andes, Clim Change 64:361-375

Haug GH, Hughen, KA, Sigman DM et al (2001) Southward migration of the Intertropical Convergence Zone through the Holocene. Science 293:1304-1308

Haug GH, Gunther D, Peterson LC et al (2003) Climate and the collapse of Maya civilization. Science 299:1731-1734

Hoffmann G, Ramirez E, Taupin JD et al (2003) Coherent isotope history of Andean ice cores over the last century. Geophys Res Lett 30:doi:10.1029/2002GL014870

Hurrell JW, van Loon H (1997) Decadal variations in climate associated with the North Atlantic Oscillation, Clim Change 36:301-326 
INTECSA (1993) Estudio de Climatologia. Plan director global binacional de proteccion -prevencion de inundaciones y aprovechamiento de los recursos del Lago Titicaca, Rio Desaguadero, Lago Poopo y Lago Salar de Coipasa (Sistema T.D.P.S). INTECSA, AIC, CNR

Jennerjahn TC, Ittekkot V, Arz HW et al (2002) Asynchronous terrestrial and marine signals of climate change during Heinrich events. Science 306:2236-2239

Liu J (2008) Interannual to decadal variability of precipitation in tropical South America and its relationship to the Tropical Atlantic and Pacific Oceans. Unpublished M.S. Thesis, Duke University

Majoube M (1971) Fractionnement en oxygene-18 et en deuterium entre 1'eau et sa vapeur. J Chem Phys 197:1423-1436

Mayle FE, Power MJ (2008) Impact of a drier Early-Mid-Holocene climate upon Amazonian forests. Phil Trans R Soc B 363:1829-1838

McCormac FG, Hogg AG, Blackwell PG et al (2004) SHCal04 Southern Hemisphere calibration 0-1000 cal BP. Radiocarbon 46:1087-1092

Melice JL, Roucou P (1998) Decadal time scale variability recorded in the Quelccaya summit ice core $\delta^{18} \mathrm{O}$ isotopic ratio series and its relation with the sea surface temperature, Clim Dyn 14:117-132

Mix AC, Morey AE, Pisias NG, Hostetler SW (1999) Foraminiferal faunal estimates ofpaleotemperature: Circumventing the noanalog problem yields cool ice age tropics. Paleoceanography 14:350-359

Moy CM, Seltzer GO, Rodbell DT, Anderson DM (2002) Variability of El Niño/Southern Oscillation activity at millennial timescales during the Holocene epoch. Nature 420:162-165

Nobre P, Shukia J (1996) Variations of sea surface temperature, wind stress and rainfall over the tropical Atlantic and South America. J Clim 9:2464- 2479

O'Neil JR, Clayton RN, Mayeda TK (1969) Oxygen isotope fractionation between divalent metal carbonates. J Chem Phys 51:5547-5558

Peterson LC, Haug GH, Hughen KA, Rohl U (2000) Rapid changes in the hydrologic cycle of the tropical Atlantic during the Last Glacial. Science 290:1947-1951

Peterson LC, Haug GH (2006) Variability in the mean latitude of the Atlantic Intertropical Convergence Zone as recorded by riverine input of sediments to the Cariaco Basin (Venezuela). Palaeogeogr Palaeoclimatol Palaeoecol 234:97-113

Ramirez E, Hoffman G, Taupin JD et al (2003) A new Andean deep ice core from Nevado Illimani (6350 m), Bolivia. Earth Planet Sci Lett 212:337-350

Rodbell D, Seltzer GO, Anderson DM (1999) An 15,000-year record of El Niño-driven alluviation in southwestern Ecuador. Science 283:516-520

Rozanski K, Araguas-Araguas L, Gonfiantini R (1993) Isotopic patterns in modern global precipitation. In: Swart PK, Lohmann KC, MacKenzie J, Savin S (eds.) Climate change in continental isotopic records. AGU, Washington, DC

Seager R, Kushnir Y, Visbeck M et al (2000) Causes of Atlantic Ocean climate variability between 1958 and 1998. J Clim 13:2845-2862

Seager R, Battisti, DS (2007) Challenges to our understanding of the general circulation: Abrupt climate change. In: Schneider T, Sobel AH (eds.) The global circulation of the atmosphere. Princeton University Press, Princeton

Seltzer G, Rodbell D, Burns S (2000) Isotopic evidence for late Quaternary climatic change in tropical South America. Geology 28:35-38

Servant-Vildary S, Roux M (1990) Multivariate analysis of diatoms and water chemistry in Bolivian saline lakes. Hydrobiologia 197:267-290

Stuiver M, Reimer PJ (1993) Extended ${ }^{14} \mathrm{C}$ data base and revised CALIB ${ }^{14} \mathrm{C}$ age calibration program. Radiocarbon 35:215-230

Sturm C, Hoffmann G, Langmann B (2007) Simulation of the stable water isotopes in precipitation over South America: Comparing regional to global circulation models. J Clim 20:3730-3750

Sutton RT, Hodson DLR (2003) Influence of the ocean on North Atlantic climate variability 1871-1999. J Clim 16:3296-3313 
Sylvestre F, Servant-Vildary S, Roux M (2001) Diatom-based ionic concentration and salinity models from the south Bolivian Altiplano (15-23 degrees South). J Paleolimnol 25:279-295

Tapia PM, Fritz SC, Baker PA (2003) A late Quaternary diatom record of tropical climate history from Lake Titicaca (Peru and Bolivia). Palaeogeogr Palaeoclimatol Palaeoecol 194:139-164

Theissen KM, Dunbar RB, Rowe HD, Mucciarone DA (2008) Multidecadal- to century-scale arid episodes on the northern Altiplano during the middle Holocene. Palaeogeogr Palaeoclimatol Palaeoecol 257:361-376

Thompson LG, Mosley-Thompson E, Bolzan JF, Koci BR (1985) A 1500-year record of tropical precipitation in ice cores from the Quelccaya ice cap, Peru. Science 234:361-364

Thompson LG, Mosley-Thompson E, Davis ME et al (1995) Late Glacial stage and Holocene tropical ice core records from Huascaran, Peru. Science 269:46-50

Thompson LG, Mosley-Thompson E, Henderson KA (2000) Ice-core palaeoclimate records in tropical South America since the Last Glacial Maximum. J Quat Sci 15:377-394

Thompson LG, Mosley-Thompson E, Brecher HH et al (2006) Abrupt tropical climate change: Past and present. Proc Nati Acad Sci 103:10536-10543

Torrence C, Webster PJ (1999) Interdecadal changes in the ENSO-monsoon system. J Clim 12:2679-2690

Vellinga M, Wood RA (2002) Global climatic impacts of a collapse of the Atlantic thermohaline circulation, Clim Change 54:251-267

Vimeux F, Gallaire R, Bony S et al (2005) What are the climate controls on SD in precipitation in the Zongo Valley (Bolivia): Implications for the Illimani ice core interpretation. Earth Planet Sci Lett 240:205-220

Vimeux F, Ginot P, Schwikowski M et al (2008) Climate variability during the last 1000 years inferred from Andean ice cores: A review of methodology and recent results. Palaeogeogr Palaeoclimatol Palaeoecol 281:229-241; doi:10.1016/j.palaeo.2008.03.054

Vogt HJ (1978) Isotopentrennun bei der Verdunstun von Wasser. Thesis, Institute of Environmental Physics, University of Heidelberg, $78 \mathrm{pp}$

Vuille M, Bradley R, Werner M et al (2003a) Modeling $\delta^{18} \mathrm{O}$ in precipitation over the tropical Americas: 1. interannual variability and climatic controls. J Geophys Res 108:doi: 10.1029/2001 JD002038

Vuille M, Bradley R, Healy R et al (2003b) Modeling $\delta^{18} \mathrm{O}$ in precipitation over the tropical Americas: 2. Simulation of the stable isotope signal in Andean ice cores. J Geophys Res 108:doi:10.1029/2001JD002039

Wang X, Auler AS, Edwards RL et al (2004) Wet periods in northeastern Brazil over the past $210 \mathrm{kyr}$ linked to distant climate anomalies. Nature 432:740-743

Wang X, Auler AS, Edwards R et al (2006) Interhemispheric anti-phasing of rainfall during the last glacial period. Quat Sci Rev 25:3391-3403

Wang X, Auler AS, Edwards RL (2007) Millennial-scale precipitation changes in southern Brazil over the past 90,000 years. Geophys Res Lett 34:L23701, doi: 10.1029/2007GL031149

Xie SP, Tanimoto Y (1998) A pan-Atlantic decadal climate oscillation. Geophys Res Lett 25: 2185-2188

Xie SP, Carton JA (2004) Tropical Atlantic variability: Patterns, mechanisms, and impacts. In: Wang C, Xie SP, Carton JA (eds.) Earth climate: The ocean-atmosphere interaction. Geophysical Monograph, 147, AGU, Washington, DC

Yu L, Jin X, Weller RA (2006) Role of net surface heat flux in seasonal variations of sea surface temperature in the tropical Atlantic Ocean. J Clim 19:6153-6169

Zeng N, Yoon J, Marengo J, (2008) Causes and impacts of the 2005 Amazon drought. Environ Res Lett 3; doi: 10.1088/1748-9326/3/1/014002

Zhang R, Delworth TL (2005) Simulated tropical response to a substantial weakening of the Atlantic thermohaline circulation. J Clim 18:1853-1860 